\title{
Effect of Preharvest Application of a Second-generation Harpin Protein on Microbial Quality, Antioxidants, and Shelf Life of Fresh-cut Lettuce
}

\author{
Jorge M. Fonseca ${ }^{2}$ and Hyun-Jin Kim ${ }^{1}$ \\ The University of Arizona, Yuma Agricultural Center, 6425 8th Street, Yuma AZ 85364 \\ Wesley L. Kline and Christian A. Wyenandt \\ Rutgers Cooperative Extension, Bridgeton, NJ 08302 \\ Murshidul Hoque and Husein Ajwa \\ University of California, Davis/USDA-ARS, Salinas, CA 93905 \\ Ned French \\ Plant Health Care Inc., Little Rock, AR 72223
}

AdDitIONAL INDEX wORDs. elicitor, minimally processed, oxidation, phenolics, postharvest

\begin{abstract}
The effect of preharvest application of a newly developed second-generation harpin product (2G-Harpin) on shelf life of fresh-cut lettuce (Lactuca sativa) was investigated. The lettuce plants were grown in three locations in the United States: Watsonville, CA, Cedarville, NJ, and Yuma, AZ, and treated 5 days before harvest at 140, 280, and $420 \mathrm{~g} \cdot \mathrm{ha}^{-1}\left(30,60\right.$, and $\left.90 \mathrm{mg} \cdot \mathrm{L}^{-1}\right)$. Lettuce processed and bagged were stored at 1 to $3{ }^{\circ} \mathrm{C}$ and evaluated for quality for 20 days. Lettuce from California treated with $2 \mathrm{G}-\mathrm{Harpin}$ at 280 to $420 \mathrm{~g} \cdot \mathrm{ha}^{-1}$ consistently showed better visual quality and lower microbial population than the control. Overall results in New Jersey showed no major differences among treatments. In Arizona, microbial population was lower and visual quality was higher in lettuce treated at 280 and 420 $\mathrm{g} \cdot \mathrm{ha}^{-1}$ during part of the storage period. In further experimentation, we examined the phenolic content of lettuce harvested 1 and 7 days after treatment with 2G-Harpin. The results showed that phenolic content was higher in all treated lettuce than in the control lettuce after $24 \mathrm{~h}$. Six days later, the levels fell back to the initial stage. Antioxidants capacity increased by $40 \%$ in head leaves when plants were treated with 280 and $420 \mathrm{~g} \cdot \mathrm{ha}^{-1} 2 \mathrm{G}-\mathrm{Harpin}$, but no change was observed in outer leaves. Overall, it was revealed that a field application of $2 \mathrm{G}-\mathrm{Harpin}$ can improve quality of fresh-cut lettuce under environmental conditions that need to be determined. Our results with phenolic content and antioxidant activity suggested that improvement in quality is probably the result of alteration of metabolites' composition and demonstrated that increased phenolics do not correlate with lower quality of fresh-cut products.
\end{abstract}

The fresh-cut industry is one of the food segments that have shown the highest growth in sales during the last few years (Clement, 2004). Fresh-cut products are commonly consumed directly from the bags without any further rinse, a convenience that is one of the main reasons for the growing popularity of these products. Strict hygiene programs have been implemented by fresh-cut companies from harvest to packaging; however, the industry has been impacted by several foodborne outbreaks associated with minimally processed vegetables (Francis et al., 1999).

It is of general consensus that despite the availability of various sanitizers approved for postharvest decontamination, the most efficient means to ensure quality of ready-to-eat commodities is to prevent high microbial loads and contamination in the fields (Abadias et al., 2008; Francis et al., 1999; Sapers, 2001). A review of assessments of a currently approved

Received for publication 14 July 2008. Accepted for publication 29 Oct. 2008. We thank Ramiro Galvez for his assistance in the Watsonville and Yuma trials. We also thank Plant Health Care, Inc. (former Eden BioSciences, Inc.) for the funding support to conduct this study.

${ }^{1}$ Current address: Division of Food Function Research, Korea Food Research Institute, Republic of Korea.

${ }^{2}$ Corresponding author. E-mail: jfonseca@ag.arizona.edu. mechanism of interventions on fresh-cut product decontamination showed that a two- or three-order reduction of microorganisms is the highest level commonly achieved (Fonseca, 2006b).

Although products such as pesticides, fertilizers, growth regulators, and biostimulants are of common use in agriculture, very little is known about the effect of those on the microbial quality of vegetables at harvest. Research in this area has mainly focused on the potential contamination introduced to fields with foliar applications of chemicals. It has been reported that some fungicide preparation can harbor microbial growth (Guan et al., 2005).

Harpin, a proteinaceous bacterial elicitor initially isolated from Erwinia amylovora (Wei et al., 1992) and later from different plant pathogens, has been reported to induce a hypersensitive reaction and a variety of defense responses such as oxidative burst and defense gene expression in plants or in cell cultures (Baker et al., 1993; He et al., 1993; Popham et al., 1995; Xie and Chen, 2000). The harpin protein, when applied to growing plants, elicits disease resistance through a systemicacquired resistance pathway (Dong et al., 1999), in particular as a result of an internal active fragment located in the amino terminal part (Jin et al., 1997). 
Postharvest treatments of harpin suppressed lesions Trichothecium roseum on the peel surface of hami melons (Cucumis melo var. inodorus), an effect that was associated with the activation of the L-phenyl oxidase enzyme (Yang et al., 2005). Thus, it was suggested that increased accumulation of phenolics may be an indirect means to control growth of plant pathogens. This prompted us to evaluate the effect of harpin on microbial quality of fresh-cut lettuce. The object of this work was to evaluate a newly developed second-generation harpin applied a few days before harvest to a head lettuce field on different quality parameters of fresh-cut lettuce. Furthermore, we examined antioxidant content to determine any relationship with the postprocessing quality.

\section{Materials and Methods}

Three field experiments were conducted during 2005 in different commercial production areas of the United States. The lettuce plants were grown in three locations: Watsonville, CA

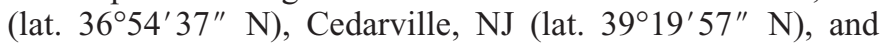
Yuma, AZ (lat. 32 $43^{\prime} 26^{\prime \prime} \mathrm{N}$ ). Mature plants were treated with 2G-Harpin (code EBC-351; Plant Health Care, Little Rock, AR) $5 \mathrm{~d}$ before harvest at 140, 280, and $420 \mathrm{~g} \cdot \mathrm{ha}^{-1}(30,60$, and $\left.90 \mathrm{mg} \cdot \mathrm{L}^{-1}\right)$.

In the California trial, the study was conducted on 'Sniper' head lettuce cultivated commercially by a local grower. The planting was done on 8 July 2005 and the harvest on 14 Sept. 2005. All irrigation water used was provided with an overhead sprinkling system.

In the New Jersey trial, the study included 'Desert Queen' head lettuce and was planted on 9 Aug. 2005. Plants were grown in a plastic mulched-drip system. The selected field was part of a commercial leafy green ranch. Harvest was done on 20 Oct. 2005.

In the Arizona trial, the study was conducted using 'Sahara' head lettuce cultivated following local commercial practices at the Yuma Agricultural Center, Yuma, AZ. The planting was on 21 Sept. 2005 and harvest was on 20 Dec. 2005. Water for germination of seeds was provided with a sprinkler system. The plants were then watered with furrow irrigation during the entire experiment.

Application of treatments and evaluations. The treatments in the three trials were: 1) control (tap water only); 2) 2GHarpin at $\left.120 \mathrm{~g} \cdot \mathrm{ha}^{-1}\left(30 \mathrm{mg} \cdot \mathrm{L}^{-1}\right) ; 3\right)$ 2G-Harpin at $280 \mathrm{~g} \cdot \mathrm{ha}^{-1}$ $\left(60 \mathrm{mg} \cdot \mathrm{L}^{-1}\right)$; and 4) $2 \mathrm{G}-$ Harpin at $420 \mathrm{~g} \cdot \mathrm{ha}^{-1}\left(90 \mathrm{mg} \cdot \mathrm{L}^{-1}\right)$. The application volume was $440 \mathrm{~L} \cdot \mathrm{ha}^{-1}$. The product was sprayed $5 \mathrm{~d}$ before harvest. The temperature during application was 12.5 to $15.5^{\circ} \mathrm{C}$. Mature plants in 18 beds (with three corresponding to one replicate) of 107 (Arizona) or $102 \mathrm{~cm}$ (New Jersey and California) were treated with the product. The length of each bed was $200 \mathrm{~m}$ in California and New Jersey and $400 \mathrm{~m}$ in Arizona. Only plants from the center beds were harvested for the study.

Lettuce heads from six different replicates were transported immediately after harvest and stored inside insulated coolers at 1.11 to $2.7^{\circ} \mathrm{C}$. After $3 \mathrm{~h}$, the lettuce was cut in pieces of 2.5 to $5.0 \mathrm{~cm}^{2}$ and placed in low-density nonperforated polyethylene Ziploc $^{\circledR}$ bags (S.C. Johnson \& Son, Racine, WI). The temperature during processing was 4.44 to $7.2^{\circ} \mathrm{C}$. The storage bags contained $450 \pm 25 \mathrm{~g}$ of processed lettuce. Six bags were produced from each replication per evaluation time for a total of 144 bags per treatment.
Evaluation of QUALity PARAmeters. The parameters of evaluation were: 1) overall visual quality (OVQ) was rated using a hedonic 0 to 9 scale in which $9=$ excellent, $7=\operatorname{good}, 5=$ fair, 3 = poor, and $1=$ unusable. The salability point on this scale was 6. 2) Browning edges (oxidation of tissue) were evaluated using a 0 to 5 severity scale in which 0 was no browning and 5 was severe browning of edges. This parameter also was assessed by separating pieces that evidenced oxidation. A composite sample of $200 \mathrm{~g}$ was taken from all six bags per replicate and the percentage of pieces with "brown" tissue was calculated by weight differential. 3) Color was measured using a C-400 Minolta Chroma meter (Konica Minolta Holdings, Tokyo, Japan). L*, a*, b* parameter units were used, with $\mathrm{L}^{*}$ denoting lightness/darkness, in which 0 is black and 100 is white; $\mathrm{a}^{*}$ green (negative) to red (positive); and $\mathrm{b}^{*}$ blue (negative) to yellow (positive). Two triplicated measurements per bag were taken. 4) Decay/breakdown/sliminess was evaluated using a 0 to 5 severity scale in which 0 was no breakdown and 5 was severe breakdown. 5) Aroma was evaluated with a 1 to 5 scale in which 1 was no aroma and 5 was full lettuce aroma. 6) Crispness was estimated using a 1 to 5 scale in which 5 was full crispness and 1 denoted lack of crispness. This was conducted subjectively by breaking midrib pieces. 7) Off odor was evaluated with a 1 to 5 scale in which 1 was no presence of abnormal aroma and 5 was a very strong rotten-type aroma. 8) Total aerobic plate count (APC) was carried out to determine microbial load. Seven grams of cut lettuce was removed from the bags and placed into a stomacher bag with $70 \mathrm{~mL}$ of sterile water and the mixture was subjected to agitation in a laboratory blender (Stomacher 400; Seward, London, U.K.) at $260 \mathrm{rpm}$ for $210 \mathrm{~s}$. One milliliter of the solution of the mixture or the solution-diluted to $10^{-3}$ to $10^{-7}$ was inoculated on APC Petrifilm ${ }^{\mathrm{TM}}$ plates $(3 \mathrm{M}$, St. Paul, MN). The plates were incubated at $32{ }^{\circ} \mathrm{C}$ for $48 \mathrm{~h}$ and the developing red-colored colonies were reported as colony-forming units. For subjective parameters, the criterion used was based on the opinion of three different judges. Evaluation of the lettuce was conducted in 5-d intervals for $20 \mathrm{~d}$. We report the most significant results obtained with selected variables.

Phenolic analysis. The harvested head lettuces were divided into inner (head) and outer leaves and both batches were completely dried using a freeze dryer (Labconco, Kansas City, MO). The dried samples were ground and kept in a freezer $\left(-80^{\circ} \mathrm{C}\right)$ until digestion procedures. Inner and outer leaves were kept separately throughout the entire process. To extract phenolic compounds, the ground sample $(0.1 \mathrm{~g})$ was mixed with $5 \mathrm{~mL}$ of $80 \%$ methanol and the mixture was shaken at room temperature for $12 \mathrm{~h}$. After centrifugation at $2000 \mathrm{~g}_{\mathrm{n}}$ for $10 \mathrm{~min}$, the methanol supernatant was used for the determination of phenolic compounds.

The total amount of phenolic compounds was determined using Folin-Ciocalteu's reagent (Sigma, St. Louis, MO) by the method of Singleton and Rossi (1965). Fifty microliters of the methanolic extract was mixed with $450 \mu \mathrm{L}$ of distilled water and $250 \mu \mathrm{L}$ of $2 \mathrm{~N}$ Folin-Ciocalteu reagents. The mixture added to $1.25 \mathrm{~mL}$ of $20 \% \mathrm{Na}_{2} \mathrm{CO}_{3}$ was incubated at $25^{\circ} \mathrm{C}$ for $20 \mathrm{~min}$ and then centrifuged at $2000 \mathrm{~g}_{\mathrm{n}}$ for $10 \mathrm{~min}$. The absorbance of the supernatant was measured at $735 \mathrm{~nm}$ and the standard curve was prepared using gallic acid (GA). The absorbance was converted to the content in terms of milligram GA equivalent per gram dry weight (DW) of sample. 
DETERMination of ANTIOXIDANT ACTIVITY. The antioxidant capacity of head lettuce was determined by the $\mathrm{DPPH}^{\circ}$ free radical scavenging assay according to the method of Yamaguchi et al. (1998) with slight modification. The reaction mixture containing $0.1 \mathrm{~mL}$ of sample, $0.4 \mathrm{~mL}$ of $0.1 \mathrm{M}$ Tris- $\mathrm{HCl}$ (pH 7.4), and $0.5 \mathrm{~mL}$ of $0.3 \mathrm{~mm} \mathrm{DPPH}^{\circ}$ was shaken and incubated in the dark at room temperature for $20 \mathrm{~min}$. After incubation, the absorbance of the reaction mixture was measured at $517 \mathrm{~nm}$ and the scavenging activity of $\mathrm{DPPH}^{*}$ free radical was calculated by the following formula:

Scavenging activity $(\%)=\left(1-\frac{\text { absorbance of sample at } 517 \mathrm{~nm}}{\text { absorbance of control at } 517 \mathrm{~nm}}\right)$ $\times 100$

A standard curve was prepared using Trolox and DPPH ${ }^{*}$ free radical scavenging activity (\%) and the antioxidant activity was calculated using the previous equation and reported as micromos Trolox equivalent per gram DW of sample.

Statistical Analysis. The experimental design for all three trials was a randomized complete block with six replicates. This design was used for the placement of treatments in the field, whereas a completely randomized design was used for allocation of treatments in the coolers. Data were subjected to analysis of variance separately for each location at $P \leq 0.05$ to determine statistical significance. Mean comparisons were conducted using Duncan's multiple range test at $P \leq 0.05$ (SAS Institute, Cary, NC).

\section{Results and Discussion}

Results obtained from the three locations varied. Five days after harvest, the lettuce in the California trial treated at 140 to $280 \mathrm{~g} \cdot \mathrm{ha}^{-1}$ had a higher OVQ and lower microbial population than the control. In New Jersey, where wet conditions prevailed immediately after treatment application and during harvest, despite a negative linear trend where higher concentration showed lower microbial population, no difference $(P<0.05)$ was observed in microbial population. OVQ, however, was higher in the 280 and $420 \mathrm{~g} \cdot \mathrm{ha}^{-1}$ treatments. In the Arizona trial, lettuce from the control showed higher microbial population than lettuce treated at 280 and $420 \mathrm{~g} \cdot \mathrm{ha}^{-1}$ and lower OVQ than the $280 \mathrm{~g} \cdot \mathrm{ha}^{-1}$ 2G-Harpin treatment (Table 1). Similar results were obtained 10 and $20 \mathrm{~d}$ after harvest (data not shown).

Readings of $\mathrm{L}^{*}$ color parameters evidenced several significant differences between treated lettuce and the control. In the California trial, the control consistently yielded lower L* units than the treatment at 280 and $420 \mathrm{~g} \cdot \mathrm{ha}^{-1}$, indicating that browning of edges was more developed in the control (Fig. 1). In the New Jersey trial, lettuce treated with 2G-Harpin at

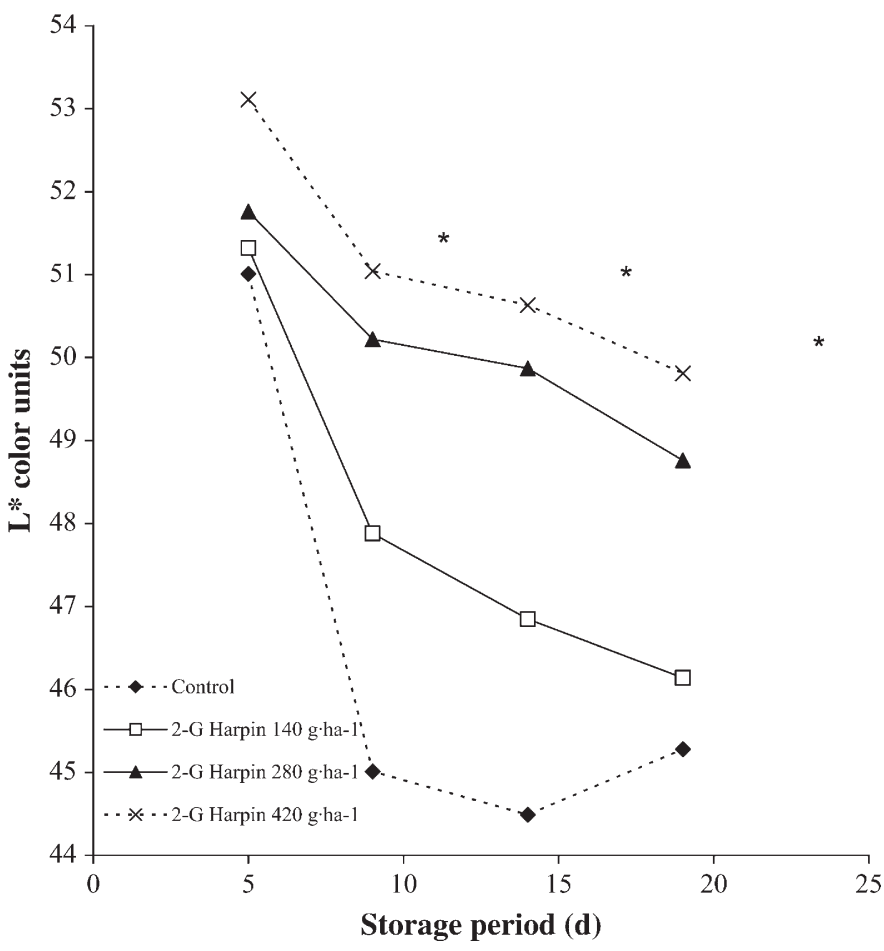

Fig. 1. Effect of a single preharvest application of 2G-Harpin to lettuce grown in Watsonville, CA, on L* color units of fresh-cut lettuce. Lower numbers indicate darker color, commonly associated with browning of edges. No measurement on Day 0 was recorded. *Difference among treatments $(P<0.05)$

$280 \mathrm{~g} \cdot \mathrm{ha}^{-1}$ showed higher $\mathrm{L}^{*}$ than the control in the last evaluation (Fig. 2), $20 \mathrm{~d}$ after harvest. In the Arizona trial, the lettuce treated with $280 \mathrm{~g} \cdot \mathrm{ha}^{-1}$ had higher L* values than the control in evaluations conducted 5, 15, and $20 \mathrm{~d}$ after harvest. The other 2G-Harpin-treated plants also had higher L* units than the control on evaluations conducted 15 and $20 \mathrm{~d}$ after harvest (Fig. 3). Because rapid decay of cut lettuce occurs even under cold storage, the decrease in lightness with time is expected because it is associated with browning appearance and quality loss (Rico et al., 2008). Ratings of "brown edges" followed the same trend observed with $\mathrm{L}^{*}$ values, because generally a higher amount of "brown" tissue was recorded with the control than with the two highest concentration treatments, whereas mixed results were observed with $a^{*}$ and $b^{*}$ units (data not shown).

Excess moisture during the application of treatments may alter the efficiency of $2 \mathrm{G}$-Harpin. Although no precipitation occurred during the plant's growth in the California trial, plants in the New Jersey trial received $191.6 \mathrm{~mm}$ during the entire

Table 1. Overall visual quality and total aerobic bacteria of fresh-cut lettuce previously applied with second-generation harpin protein (2GHarpin) $5 \mathrm{~d}$ after processing in the three different locations considered in this study.

\begin{tabular}{|c|c|c|c|c|c|c|}
\hline \multirow[b]{2}{*}{ Treatments } & \multicolumn{3}{|c|}{ Overall visual quality $(1-9 \text { scale })^{z}$} & \multicolumn{3}{|c|}{ Microbial population $\left(\log _{10} \mathrm{cfu} / \mathrm{g}\right)$} \\
\hline & Watsonville, CA & Cedarville, NJ & Yuma, AZ & Watsonville, CA & Cedarville, $\mathrm{NJ}$ & Yuma, AZ \\
\hline Control & $7.8 \mathrm{~b}^{\mathrm{y}}$ & $5.83 \mathrm{~b}$ & $7.61 \mathrm{~b}$ & $5.98 \mathrm{a}$ & $6.86 \mathrm{a}$ & $6.81 \mathrm{a}$ \\
\hline 2G-Harpin $140 \mathrm{~g} \cdot \mathrm{ha}^{-1}$ & $7.9 \mathrm{~b}$ & $5.89 \mathrm{~b}$ & $7.86 \mathrm{~b}$ & $5.35 \mathrm{ab}$ & $6.36 \mathrm{a}$ & $6.64 \mathrm{ab}$ \\
\hline 2G-Harpin $420 \mathrm{~g} \cdot \mathrm{ha}^{-1}$ & $8.5 \mathrm{a}$ & $6.28 \mathrm{a}$ & $8.33 \mathrm{a}$ & $5.11 \mathrm{c}$ & $6.18 \mathrm{a}$ & $6.78 \mathrm{ab}$ \\
\hline
\end{tabular}

${ }^{\mathrm{z}}$ Overall visual quality ( $0-9$ scale) in which $9=$ excellent, $7=$ good, $5=$ fair, $3=$ poor, and $1=$ unusable. Salability point in this scale was 6 .

${ }^{y}$ Values followed by different letters in the same column are significantly different $(P<0.05)$. 


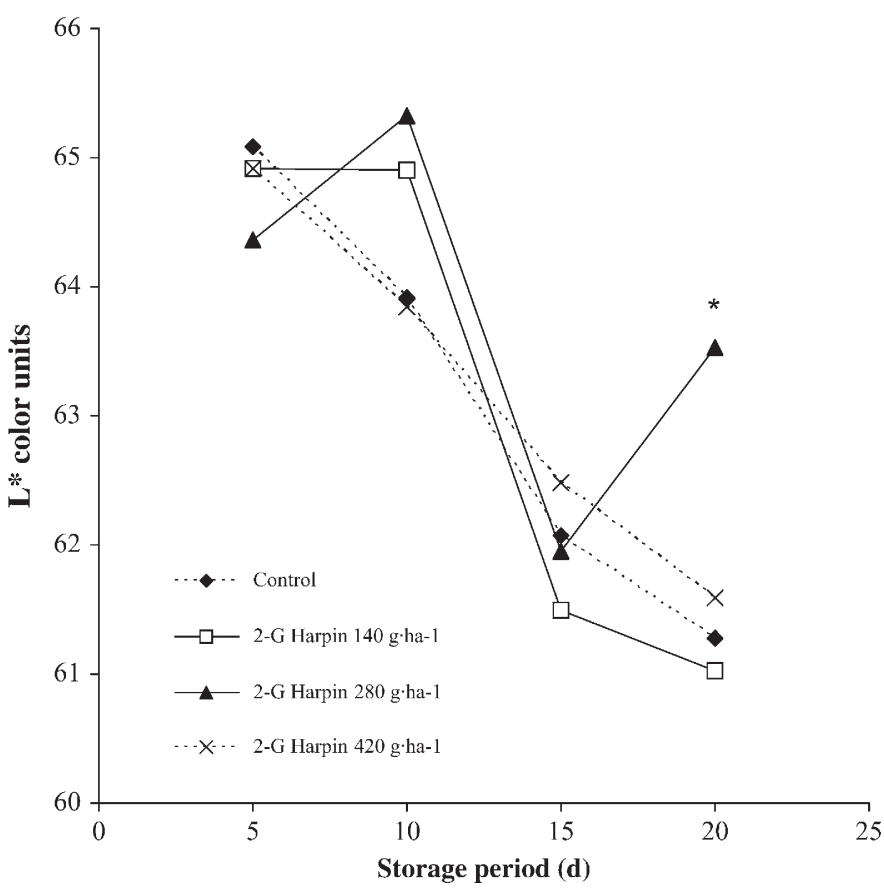

Fig. 2. Effect of a single preharvest application of second-generation harpin protein (2G-Harpin) to lettuce grown in Cedarville, $\mathrm{NJ}$, on $\mathrm{L}^{*}$ color units of fresh-cut lettuce. Lower numbers indicate darker color, commonly associated with browning of edges. No measurement on Day 0 was recorded. *Difference among treatments $(P<0.05)$.

growth term and $43.9 \mathrm{~mm}$ during the last $5 \mathrm{~d}$ before harvest. The plants in Arizona received $45.46 \mathrm{~mm}$ during the growth cycle, but there was no rain event during the last $5 \mathrm{~d}$ before harvest. In New Jersey, although the product was in contact with the lettuce for at least $60 \mathrm{~min}$, it is possible that rainfall, which occurred within $3 \mathrm{~h}$ from the application, had a negative impact on the treatment. Rainfall occurred daily in this location during

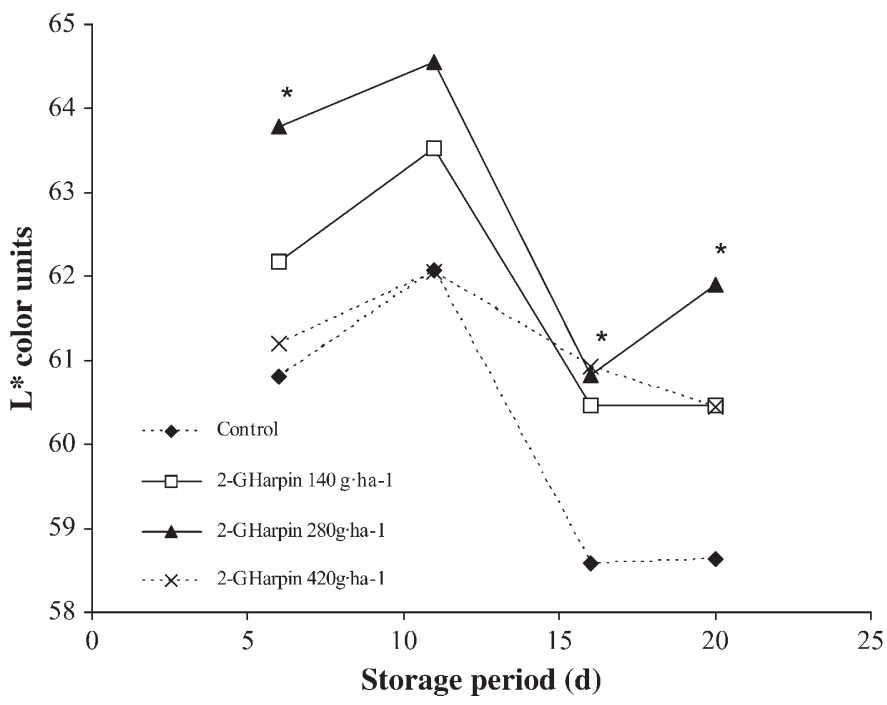

Fig. 3. Effect of a single preharvest application of second-generation harpin protein (2G-Harpin) to lettuce grown in Yuma, AZ, on L* color units of freshcut lettuce. Lower numbers indicate darker color, commonly associated with browning of edges. No measurement on Day 0 was recorded. *Difference among treatments $(P<0.05)$. the days before and after the treatment and harvest. Previous research has shown that levels of micro-organisms increase significantly in outer and inner leaves of head lettuce when excess moisture is prevalent at harvest (Fonseca, 2006a). Evaluation of elicitors of induced resistance is often difficult in field settings, because the chemical defense is a possible part of a constitutive, rather than inducible, chemical defense mechanism that is developmentally regulated and critically dependent on the environment (Delano-Frier et al., 2004). Interestingly, methyl jasmonate, a growth regulator that peaks with extreme weather conditions, may inhibit elicitor-induced hypersensitive response by harpin (Andi et al., 2001) by repressing protein syntheses that are required for translation initiation (Reinbothe et al., 1994a).

Phenolic levels in plants treated with $2 \mathrm{G}$-Harpin showed an interesting trend. Head (inner) leaves treated with $2 \mathrm{G}-$ Harpin had $25 \%$ higher content of phenolics when treated with $2 \mathrm{G}$ Harpin at 280 and $420 \mathrm{~g} \cdot \mathrm{ha}^{-1} 1 \mathrm{~d}$ before harvest. When the application was done with the lowest concentration or when it was done $7 \mathrm{~d}$ before harvest, there was no difference among treatments and control (Fig. 4). With outer leaves, all three concentrations of 2G-Harpin yielded an increase in phenolic levels when applied $7 \mathrm{~d}$ before harvest, but only the two higher concentrations produced higher phenolic levels than the control when applied $1 \mathrm{~d}$ before harvest (Fig. 5). The increase in phenolic levels observed in outer leaves ranged from $7 \%$ to $9 \%$. In general, outer leaves contained three times more phenolics than inner leaves.

The results with phenolic compounds could explain the results obtained with microbial counts. Phenolic compounds are diverse and have been extensively connected with the chemical defense of plants against microbes (Einhellig, 1986). Increased phenolic levels and compounds in roots and shoots of

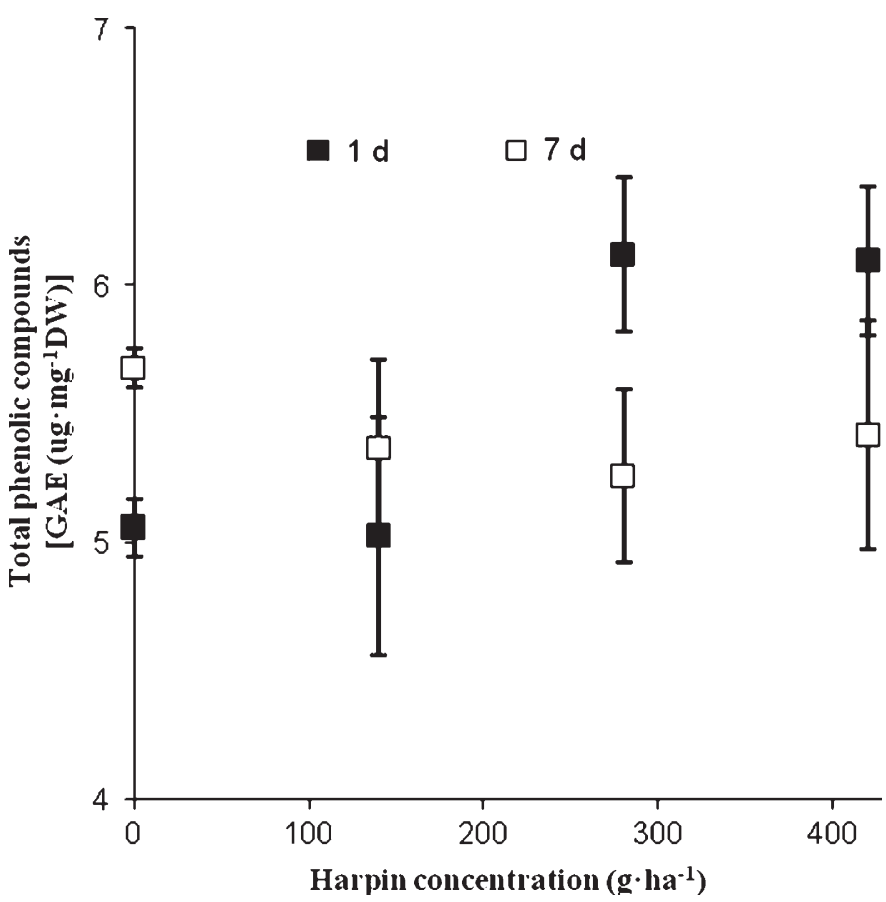

Fig. 4. Total phenolic compounds in head (inner) leaves of head lettuce treated with second-generation harpin protein (2G-Harpin) 1 and $7 \mathrm{~d}$ before harvest. $\mathrm{GAE}=$ gallic acid equivalents . 


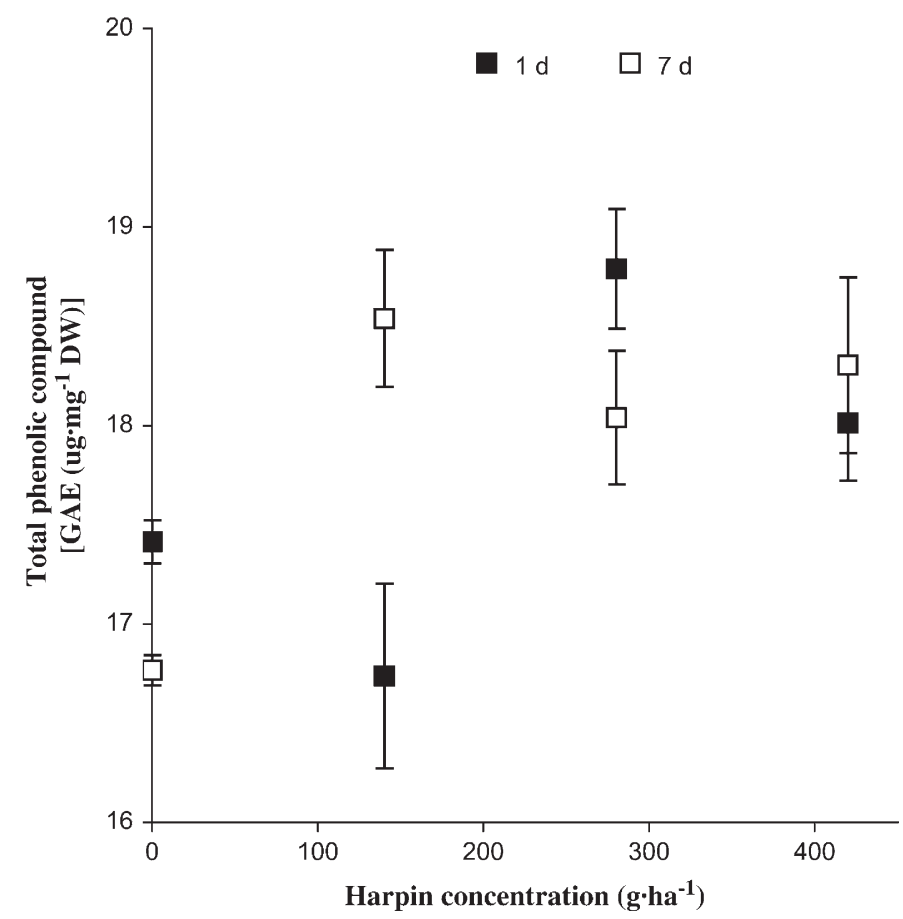

Fig. 5. Total phenolic compounds in outer leaves of head lettuce treated with second-generation harpin protein (2G-Harpin) 1 and $7 \mathrm{~d}$ before harvest. GAE $=$ gallic acid equivalents.

groundnut (Arachis hypogaea) were obtained after inoculation with vesicular-arbuscular mycorrhizal (Devi and Reddy, 2002) indicating that phenolics are the result of physiological interactions between the fungus and host. Foliar spray of Pseudomonas strains enhanced total phenolic content and salicylic acid concentration within $24 \mathrm{~h}$ of application (Singh et al., 2003). Extracts of oregano (Oreganum vulgure) have been suggested as a promising option to prevent bacteria infection in germinating sprouts by stimulating phenolic antioxidant-producing pathways while increasing the nutritional value (McCue and Shetty, 2002).

The low response in phenolic levels (inner leaves) when the product was applied $7 \mathrm{~d}$ before harvest may be the result of an immediate increase and subsequent decline. An initial increase and following decline in phenolic compound was also observed $24 \mathrm{~h}$ after treating leaves of Cicer arietinum with Pseudomonas fluorescens (Singh et al., 2003). It is possible that the decline in phenolics with time is the result of formation of lignin. There is increased evidence that multiple phenolic acids are key compounds in lignin of plants (Iiyama et al., 1994). Increased lignification in oregano plants was observed in response to treatments with acetyl salicylic acid (Andarwulan and Shetty, 1999).

An interesting aspect revealed in this work is that despite the induced accumulation of phenolics with 2G-Harpin, the postprocessing quality was improved in two of the three trials. Although this appears contradictory, that is, production of more phenolics resulting in less oxidation, our work adds to few other reports that have evidenced this particular issue (Cantos et al., 2002; Degl'Innocenti et al., 2005; Reyes et al., 2007). Methyl jasmonate is known to increase phenolics, yet the quality of fresh-cut products is also improved with the treatment (Buta and Moline, 1998). It might be possible that certain induced phenolics are less prone to oxidation than others (Kim et al., 2007), but this needs to be confirmed. It is also possible that induced phenolic profiles vary depending on the elicitor that triggers the change. Reyes et al. (2007) recently showed that phenolics are used primarily for lignin and suberin synthesis, whereas ascorbic acid is the key compound in leaf tissue, allowing the control of reactive oxygen species generated by cutting. The response to an elicitor is complex because it can be affected by the endogenous property of the plant, the type of elicitor, and by the duration of the exposure of the plant to the elicitor. Salt stress produced different changes in secondary metabolites when exposed long term as compared with a high concentration in short-term exposure (Kim et al., 2008). Elicitors such as methyl jasmonate may induce dissimilar changes in metabolites or protein in different types of leaves (Reinbothe et al., 1994b).

Browning of lettuce is not only the result of enzymatic processes. Electrolyzed water (produced by electrolysis of a $0.1 \%$ sodium chloride solution using a generator that contains an electrolytic cell) at high concentrations produced more browning of lettuce resulting from direct damage of the tissue (Rico et al., 2008). A recent study concluded that in leafy greens, ascorbic acid is the main compound responsible for controlling radical species after cutting. In tissue with low levels of reduced ascorbic acid, this compound is consumed readily and phenolics are then used to control reactive oxygen species (Degl'Innocenti et al., 2007). In our study, we did not evaluate for ascorbic acid content as affected by $2 \mathrm{G}-H a r p i n$. However, the results obtained with antioxidant capacity indicates that an increase of antioxidant(s), and not only phenolics, occurred after application of $2 \mathrm{G}-$ Harpin. Head leaves of lettuce treated with $2 \mathrm{G}-\mathrm{Harpin}$ at 280 and $420 \mathrm{~g} \cdot \mathrm{ha}^{-1}$ contained at least $40 \%$ more antioxidants than leaves of the control, whereas no difference was detected among outer leaves (Fig. 6).

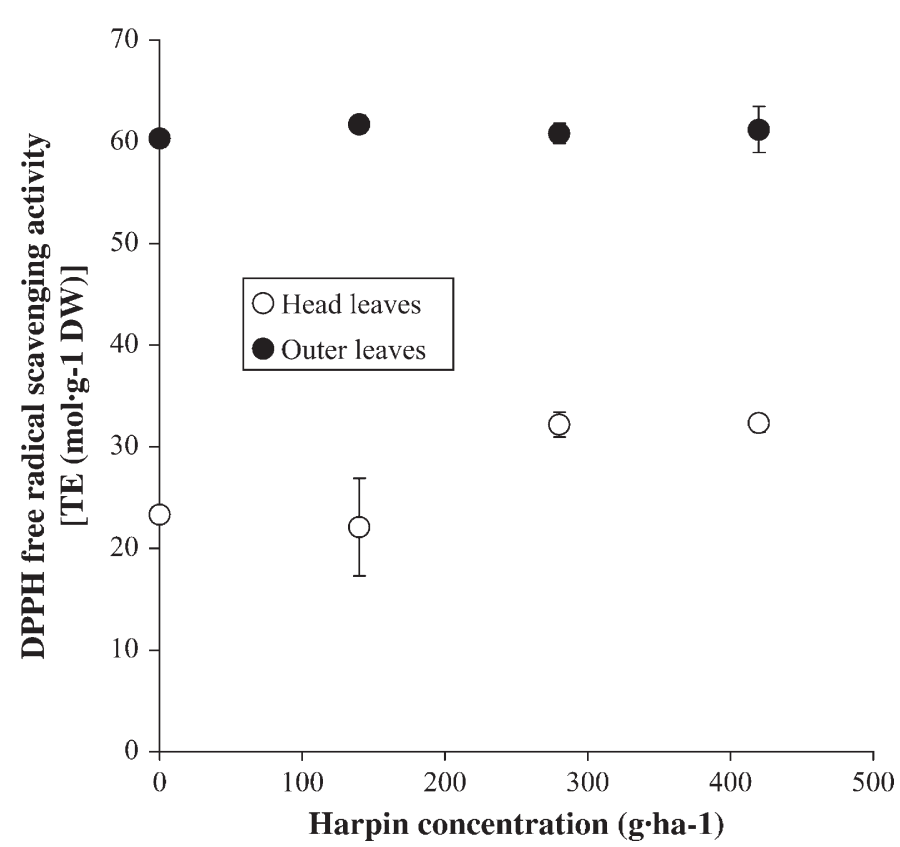

Fig. 6. Antioxidant capacity (based on DPPH · free radical scavenging capacity) of head lettuce treated with second-generation harpin protein (2G-Harpin) 1 $\mathrm{d}$ before harvest. $\mathrm{DPPH}=2,2$ diphenyl-1-picrylhydrazyl; $\mathrm{TE}=$ Trolox equivalents. 
Generally, the enhancement of polyphenoloxidase (PPO) activity, triggered by an elicitor agent or physiological (physical/environmental) stress, results in increased levels of antioxidants and/or phenolics, which is further associated with reduction of shelf life in fresh-cut lettuce (Zhang et al., 2006). However, previous studies have shown that different insects may or may not induce PPO activity (Felton et al., 1994). Stout et al. (1994) observed different PPO activity depending on the type of damage to the tissue. No correlation was obtained among phenolics, PPO, and browning of potatoes during postharvest storage (Cantos et al., 2002). It is possible that an increase in ascorbic acid correlates with a decline of PPO because it is known that ascorbic acid is a natural inhibitor of PPO (Weaver and Charley, 1974) and peroxidase oxidase (Lamikanra and Watson, 2001), the other known browningpromoter enzyme (Vamos-Vigyazo, 1981) characterized by peroxidase-catalyzed oxidation of compounds without $\mathrm{H}_{2} \mathrm{O}_{2}$ addition (Yamazaki and Yokota, 1973). The recently proposed hypotheses (Degl'Innocenti et al., 2005; Reyes et al., 2007), which states that: 1) ascorbic acid may be the main compound associated with the resistance of fresh-cut lettuce to color alteration upon storage; and 2) not all factors or elicitors that enhance phenolics decrease quality of fresh-cut product resulting from oxidation and triggers increased activity of PPO, should be considered further.

Results from Constabel and Ryan (1998) demonstrated a wide variation of PPO response among different species. Wounding (e.g., cutting) increases phenolic metabolism in lettuce leaf tissue with the production and accumulation of soluble phenolic compounds (mainly hydroxycinnamic acid conjugates such as chlorogenic acid) that subsequently react to produce wound-induced tissue browning (Tomás-Barberán et al., 1997), but PPO activity could be dependent in previous conditions. Plants that were well watered showed higher PPO activity than plants with reduced irrigation water (Barbagallo et al., 2008), which suggested that high watering levels lead to a more marked expression of degradative enzymatic activities and susceptibility to undesirable browning and softening reactions. Preharvest application of harpin protein may produce similar response to water stress without the potential risk for yield reduction. Postharvest application appears to be another potential option for harpin protein because Yang et al. (2005) extended the shelf life of hami melons at lower concentrations than $90 \mathrm{mg} \cdot \mathrm{L}^{-1}$.

Overall, this study revealed that a field application of $2 \mathrm{G}-$ Harpin can improve quality of fresh-cut lettuce under conditions to be elucidated. Our results encourage further studies to determine the influence of environmental conditions on the plant's response to harpin and demonstrate that agents that elicit hypersensitive response may be used to improve microbial and visual quality of fresh-cut products.

\section{Literature Cited}

Abadias, M., J. Usall, M. Anguera, C. Solsona, and I. Viñas. 2008. Microbiological quality of fresh, minimally-processed fruit and vegetables, and sprouts from retail establishments. Intl. J. Food Microbiol. 123:121-129.

Andarwulan, N. and K. Shetty. 1999. Influence of acetyl salicylic acid in combination with fish protein hydrolysates on hyperhydricity reduction and phenolic synthesis in oregano (Origanum vulgare) tissue cultures. J. Food Biochem. 23:619-635.

Andi, S., F. Taguchi, K. Toyoda, T. Shiraishi, and Y. Ichinose. 2001. Effect of methyl jasmonate on harpin-induced hypersensitive cell death, generation of hydrogen peroxide and expression of PAL mRNA in tobacco suspension cultured BY-2 cells. Plant Cell Physiol. 42:446-449.

Baker, C.J., E.W. Orlandi, and N.M. Mock. 1993. Harpin, an elicitor of hypersensitive response in tobacco caused by Erwinia amylovora, elicits active oxygen production in suspension cells. Plant Physiol. 102:1341-1344.

Barbagallo, R.N., M. Chisari, F. Branca, and G. Spagna. 2008. Pectin methylesterase, polyphenol oxidase and physicochemical properties of typical long-storage cherry tomatoes cultivated under water stress regime. J. Sci. Food Agr. 88:389-396.

Buta, J.G. and H.E. Moline. 1998. Methyl jasmonate extends shelf life and reduces microbial contamination of fresh-cut celery and peppers. J. Agr. Food Chem. 46:1253-1256.

Cantos, E., J.A. Tudela, M.I. Gil, and J.C. Espín. 2002. Phenolic compounds and related enzymes are not rate-limiting in browning development of fresh-cut potatoes. J. Agr. Food Chem. 50:30153023.

Clement, D.B. 2004. Fresh-cut fruit category to top \$1 billion by 2008 . Fresh-Cut 12:4-6.

Constabel, C.P. and C.A. Ryan. 1998. A survey of wound-and methyl jasmonate-induced leaf polyphenol oxidase in crop plants. Phytochemistry 47:507-511.

Degl'Innocenti, E., L. Guidi, A. Pardossi, and F. Tognoni. 2005. Biochemical study of leaf browning in minimally processed leaves of lettuce (Lactuca sativa L. var. acephala). J. Agr. Food Chem. 53:9980-9984.

Degl'Innocenti, E., A. Pardossi, F. Tognoni, and L. Guidi. 2007. Physiological basis of sensitivity to enzymatic browning in 'lettuce', 'escarole' and 'rocket salad' when stored as fresh-cut products. Food Chem. 104:209-215.

Delano-Frier, J.P., N.A. Martinez-Gallardo, O. Martinez-de la Vega, M.D. Salas-Araiza, E.R. Barbosa-Jaramillo, A. Torres, P. Vargas, and A. Borodanenko. 2004. The effect of exogenous jasmonic acid on induced resistance and productivity in amaranth (Amaranthus hypochondriacus) is influenced by environmental conditions. J. Chem. Ecol. 30:1001-1034.

Devi, M.C. and M.N. Reddy. 2002. Phenolic acid metabolism of groundnut (Arachis hypogaea L.) plants inoculated with VAM fungus and Rhizobium. Plant Growth Regulat. 37:151-156.

Dong, H.T., P. Delaney, D.W. Bauer, and S.V. Beer. 1999. Harpin induces disease resistance in Arabidopsis through the systemic acquired resistance pathway mediated by salicylic acid and the NIM1 gene. Plant J. 20:207-215.

Einhellig, F.A. 1986. Mechanism and modes of action of allelochemicals, p. 171-189. In: Putnam, A.R. and C.S. Tang (eds.). The science of allelopathy. Wiley, New York, NY.

Felton, G.W., G.B. Summers, and A.J. Mueller. 1994. Induced resistance in soybean to Helicoverpa zea: Role of plant protein quality. J. Chem. Ecol. 20:183-198.

Fonseca, J.M. 2006a. Postharvest quality and microbial population of head lettuce as affected by moisture at harvest. J. Food Sci. 71:M45M49.

Fonseca, J.M. 2006b. Postharvest handling and processing: Sources of microorganisms and impact of sanitizing procedures, p. 85-120. In: Matthews, K.R. (eds). Microbiology of fresh produce. ASM Press, Washington DC.

Francis, G.A., C. Thomas, and D. O'Beirne. 1999. The microbiological safety of minimally processed vegetables. Intl. J. Food Sci. Technol. 34:1-22.

Guan, T.T.Y., G. Blank, and R.A. Holley. 2005. Survival of pathogenic bacteria in pesticide solutions and on treated tomato plants. J. Food Prot. 68:296-304.

He, S.Y., H. Huang, and H.C. Collmer. 1993. Pseudomonas syringae pv. syringae harpin ${ }_{\text {Pss }}$ : A protein that is secreted via the Hrp pathway and elicits hypersensitive response in plants. Cell 73:1255-1266.

Iiyama, K., T.B.T. Lam, and B.A. Stone. 1994. Covalent cross-links in the cell wall. Plant Physiol. 104:315-320. 
Jin, Q.L., N.Z. Liu, J.L. Qiu, D.B. Li, and J. Wang. 1997. A truncated fragment of harpin Pss induces systemic resistance to Zanthomonas campestris pv. oryzae in rice. Physiol. Mol. Plant Pathol. 51:243-257.

Kim, H.J., J.M. Fonseca, J.H. Choi, and C. Kubota. 2007. Effect of methyl jasmonate on phenolic compounds and carotenoids of romaine lettuce (Lactuca sativa L.). J. Agr. Food Chem. 55:10366-10372.

Kim, H.J., J.M. Fonseca, C. Kubota, J.H. Choi, and D.Y. Kwon. 2008. Salt in irrigation water affects the nutritional and visual properties of romaine lettuce (Lactuca sativa L.). J. Agr. Food Chem. 56:37723776.

Lamikanra, O. and M.A. Watson. 2001. Effects of ascorbic acid on peroxidase and polyphenoloxidase activities in fresh-cut cantaloupe melon. J. Food Sci. 66:1283-1286.

McCue, P. and K. Shetty. 2002. Clonal herbal extracts as elicitors of phenolic synthesis in dark-germinate mungbeans for improving nutritional value with implications for food safety. J. Food Biochem. 26:209-232.

Popham, P., S. Pike, and A. Novacky. 1995. The effect of harpin from Erwinia amylovora on the plasmalema of suspension culture tobacco cells. Physiol. Mol. Plant Pathol. 47:39-50.

Reinbothe, S., C. Reinbothe, J. Lehmann, W. Becker, K. Apel, and B. Parthier. 1994a. JIP60, a methyl jasmonate-induced ribosomeinactivating protein involved in plant stress reactions. Proc. Natl. Acad. Sci. USA 91:7012-7016.

Reinbothe, S., B. Mollenhauer, and C. Reinbothe. 1994b. JIPs and RIPs: The regulation of plant gene expression by jasmonates in response to environmental cues and pathogens. Plant Cell 6:1197-1209.

Reyes, L.F., J.E. Villareal, and L. Cisneros-Cevallos. 2007. The increase in antioxidant capacity alter wounding depends on the type of fruit or vegetable tissue. Food Chem. 101:1254-1262.

Rico, D., A.B. Martín-Diana, C. Barry-Ryan, J.M. Frías, G.T.M. Henehan, and J.M. Barat. 2008. Use of neutral electrolised water (EW) for quality maintenance and shelf-life extension of minimally processed lettuce. Innovative Food Sci. Emerging Technol. 9:37-48. Sapers, G.M. 2001. Efficacy of washing and sanitizing methods for disinfection of fresh fruit and vegetable products. Food Technol. Biotechnol. 39:305-311.
Singh, U.P., B.K. Sarma, and D.P. Singh. 2003. Effect of plant growthpromoting rhizobacteria and culture filtrate of Sclerotium rolfsii on phenolic and salicylic acid contents in chickpea (Cicer arietinum). Curr. Microbiol. 46:131-140.

Singleton, V.L. and I.A. Rossi. 1965. Colorimetry of total phenolics with phospho- molybdic-phosphotungstic acid reagents. Amer. J. Enol. Viticult. 16:144-158.

Stout, M.J., J. Workman, and S.S. Duffey. 1994. Differential induction of tomato foliar proteins by arthropod herbivores. J. Chem. Ecol. 20:2575-2594.

Tomás-Barberán, F.A., J. Loaiza-Velarde, A. Bonfanti, and M.E. Saltveit. 1997. Early wound- and ethylene-induced changes in phenylpropanoid metabolism in harvested lettuce. J. Amer. Soc. Hort. Sci. 122:399-404.

Vamos-Vigyazo, L. 1981. Polyphenol oxidase and peroxidase in fruits and vegetables. Crit. Rev. Food Sci. Nutr. 15:49-127.

Weaver, G. and H. Charley. 1974. Enzymatic browning of ripening bananas. J. Food Sci. 39:1200-1202.

Wei, Z.M., R.J. Laby, C.H. Zumoff, D.W. Bauer, S.Y. He, A. Collmer, and S.V. Beer. 1992. Harpin elicitor of the hypersensitive response produced by the pathogen Erwinia amylovora. Science 257:8588.

Xie, Z. and Z. Chen. 2000. Harpin-induced hypersensitive cell death is associated with altered mitochondrial functions in tobacco cells. Mol. Plant Microbe Interact. 11:1621-1639.

Yamaguchi, T., H. Takamura, T. Matoba, and J. Terao. 1998. HPLC method for evaluation of the free radical-scavenging activity of foods by using 1,1-diphenyl-2-picrylhydrazyl. Biosci. Biotechnol. Biochem. 62:1201-1204.

Yamazaki, I. and K. Yokota. 1973. Oxidation states of peroxidase. Mol. Cell. Biochem. 2:39-52.

Yang, B., T. Shiping, Z. Jie, and G. Yonghong. 2005. Harpin induces local and systemic resistance against Trichothecium roseum in harvested hami melons. Postharvest Biol. Technol. 38:183-187.

Zhang, L., L. Zhaoxin, L. Fengxia, and B. Xiaomei. 2006. Effect of $\gamma$ irradiation on quality-maintaining of fresh-cut lettuce. Food Contr. 17:225-228. 